\title{
Regulation of Synthesis and Reversible Inactivation in vivo of Dual Coenzyme-specific Glutamate Dehydrogenase in Bacteroides fragilis
}

\author{
By ISAMU YAMAMOTO,* HIROYUKI SAITO AND MAKOTO ISHIMOTO \\ Department of Chemical Microbiology, Faculty of Pharmaceutical Sciences, Hokkaido University. \\ Sapporo 060, Japan
}

(Received 5 January 1987; revised 9 June 1987)

\begin{abstract}
Regulation of the dual coenzyme-specific glutamate dehydrogenase (GDH; EC 1.4.1.3) was studied in the anaerobic bacterium Bacteroides fragilis. Cells grown at a low concentration of ammonia had a specific activity for the enzyme 10-fold higher than that for cells grown with excess ammonia. Immunochemical determination with a GDH-specific antiserum showed that the content of immuno-precipitated protein was about $8 \%$ of the total protein in the former cells and was $4 \%$ in the latter cells. When cells grown on $50 \mathrm{~mm}-\mathrm{NH}_{4} \mathrm{Cl}$ were transferred to a fresh medium containing $0.5 \mathrm{~mm}-\mathrm{NH}_{4} \mathrm{Cl}$, an increase in the molecular activity of the enzyme occurred, and synthesis of immuno-reactive protein started. Rapid inactivation of the GDH occurred when cells grown on $1 \mathrm{~mm}-\mathrm{NH}_{4} \mathrm{Cl}$ were exposed to $50 \mathrm{~mm}-\mathrm{NH}_{4} \mathrm{Cl}$. However, the amount of immuno-precipitated protein was not decreased. The inactivation was specifically induced by ammonia and was reversed by transferring the cells to an ammonia-limited medium even in the presence of chloramphenicol. These findings suggest that the synthesis of the GDH is stimulated under low ammonia conditions and that the enzyme activity is controlled by means of a reversible activation/inactivation mechanism which is regulated by ammonia. However, no phosphorylation of GDH was observed before and after exposure of cells to high concentrations of ammonia.
\end{abstract}

\section{INTRODUCTION}

Bacteroides fragilis is a strictly anaerobic bacterium predominating in the human intestinal tract (Finegold et al., 1974; Moore \& Holdeman, 1974) and frequently found in clinical isolates (Finegold, 1977). In B. fragilis, glutamate dehydrogenase (GDH) provides the principal means of incorporation of ammonia into glutamate even under ammonia-limited conditions (Yamamoto et al., 1984). This anaerobe contains two electrophoretically distinct GDHs: one of them has dual specificity for pyridine nucleotides, and the other is NAD+-specific. The dual coenzyme-specific GDH (EC 1.4.1.3) has been purified and characterized (Yamamoto et al., 1987). This enzyme shows relatively high affinity for ammonia $\left(K_{\mathrm{m}}\right.$ about $\left.1 \mathrm{mM}\right)$ in the NADPHdependent amination. Enzyme activities with $\mathrm{NAD}(\mathrm{P}) \mathrm{H}$ and $\mathrm{NAD}(\mathrm{P})^{+}$are not controlled by amino acids, dicarboxylic acids or adenine nucleotides. Higher NADPH-dependent activity is found in cells grown in a medium containing a low concentration of ammonia. The $\mathrm{NAD}^{+-}$ specific enzyme is induced, to a small extent, only under conditions of excess ammonia. $B$. fragilis cannot use amino acids as a nitrogen source (Varel \& Bryant, 1974) and the cellular levels of the GDHs are not affected by the presence of glutamate in the growth medium (Yamamoto $e t$ al., 1984). Some properties of the dual-specificity enzyme purified from Bacteroides thetaiotaomicron have also been investigated by Glass \& Hylemon (1980). The presence of a similar enzyme has been demonstrated in the other species of the DNA homology group in the

Abbreviation: GDH, glutamate dehydrogenase. 
genus Bacteroides (Glass \& Hylemon, 1980; Shah \& Williams, 1982). However, the mechanism of its regulation is not understood.

In this study the regulatory properties of the dual coenzyme-specific GDH in B. fragilis were investigated using a specific antiserum against the purified enzyme.

\section{METHODS}

Organism and culture. Bacteroides fragilis ATCC 23745 was grown anaerobically in the defined medium described previously (Yamamoto et al., 1984). The $\mathrm{NH}_{4} \mathrm{Cl}$ concentrations were as indicated. Cultures incubated

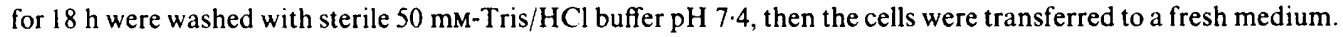
When cultures were exposed to ammonia shock, $\mathrm{NH}_{4} \mathrm{Cl}$ solutions were added to $18 \mathrm{~h}$ cultures originally containing I mM- $\mathrm{NH}_{4} \mathrm{Cl}$ to give a final concentration of $50 \mathrm{~mm}$.

Preparation of crude extracts. Cells were harvested by centrifugation at $12000 \mathrm{~g}$ for $10 \mathrm{~min}$ and disrupted with a sonicator (Tomy model $150 \mathrm{P}$ ) at $20 \mathrm{kHz}$ and $74 \mathrm{~W}$ for $5 \mathrm{~min}$ in 4 vols of $50 \mathrm{~mm}-\mathrm{Tris} / \mathrm{HCl} \mathrm{pH} \mathrm{7.6}$. The supernatants, following centrifugation at $15000 \mathrm{~g}$ for $15 \mathrm{~min}$, were used as crude extracts.

Assay of enzyme activities. All enzyme activities were assayed at $30^{\circ} \mathrm{C}$. For assaying GDH activities, the decrease in the absorption of $\mathrm{NAD}(\mathrm{P}) \mathrm{H}$ at $340 \mathrm{~nm}$ was monitored with a recorder-equipped spectrophotometer (Jasco model Uvidec-340). The reaction mixture contained $0.1 \mathrm{M}$-Tris- $\mathrm{HCl} \mathrm{pH} 8.0,0.15 \mathrm{~mm}-\mathrm{NADPH}, 40 \mathrm{~mm}$ $\mathrm{NH}_{4} \mathrm{Cl}$ and $5 \mathrm{~mm}-2$-oxoglutarate. $\mathrm{NADH}$-dependent activity was assayed at $\mathrm{pH} 7 \cdot 4$.

One unit of enzyme activity was defined as the amount of enzyme that catalysed the oxidation of $1 \mu \mathrm{mol}$ $\mathrm{NAD}(\mathrm{P}) \mathrm{H} \mathrm{min}^{-1}$.

Protein was assayed by the Lowry method, using bovine serum albumin as standard.

PAGE. Crude extracts were subjected to electrophoresis by the method of Davis (1964). After electrophoresis, the gels were stained for enzyme activity. The staining solution consisted of $50 \mathrm{~mm}$-Tris $/ \mathrm{HCl} \mathrm{pH} 8.6,1 \mathrm{~mm}$ $\mathrm{NADP}^{+}, 10 \mathrm{~mm}$-glutamate, $1 \mathrm{~mm}$-phenazine methosulphate (Sigma) and $0 \cdot 2 \%$ triphenyltetrazolium chloride.

Preparation of antiserum. The purified enzyme (Yamamoto et al., 1987) containing hexameric and dodecameric enzymes (homogeneous by SDS-PAGE) was used to immunize a male rabbit. Approximately $90 \mu \mathrm{g}$ of the GDH protein mixed with Freund's complete adjuvant was injected subcutaneously into the back of the rabbit. This was repeated several times at intevals of 7 10 d. Blood was collected every week after the 3 rd injection until the cross reactivity in the serum became low. The blood was allowed to clot and was then centrifuged at $8000 \mathrm{~g}$ for $5 \mathrm{~min}$. The supernatant obtained was used as the antiserum.

Immunological techniques. The isolation of immunoglobulins and other immunological methods were according to Johnstone \& Thorpe (1982).

Antibody reaction was tested using the Ouchterlony double immunodiffusion method in a $1 \%(w / v)$ agarose gel containing $10 \mathrm{~mm}$-potassium phosphate $\mathrm{pH} 7.8$ and $0.15 \mathrm{M}-\mathrm{NaCl}$.

Immunoelectrophoresis was done in $12 \mathrm{ml} \mathrm{1.2 \%} \mathrm{agarose} \mathrm{with} \mathrm{a} 30 \mathrm{mM}$-barbital buffer $\mathrm{pH} 8.3$ as the electrolyte, on glass plates $(10 \times 6 \mathrm{~cm})$ at $4{ }^{\circ} \mathrm{C}$ in a water-cooled electrophoresis chamber (Bio-Rad model 1415). About $5 \mu \mathrm{l}$ of extract (approximately $100 \mu \mathrm{g}$ protein) in each well ( $3 \mathrm{~mm}$ diameter) was electrophoresed at $2.5 \mathrm{~mA}$ per $6 \mathrm{~cm}$ of gel width for about $4 \mathrm{~h}$. The antiserum was added to troughs made on the gels and incubated at $4{ }^{\circ} \mathrm{C}$.

Rocket immunoelectrophoresis was done in $24 \mathrm{ml} 1 \%$ agarose containing the barbital buffer and $5 \%(\mathrm{v} / \mathrm{v})$ of the anti-GDH antiserum, on glass plates $(10 \times 12 \mathrm{~cm})$ in the cooled electrophoresis chamber. The purified enzyme was used as a standard for assaying immuno-reactive protein. After electrophoresis at $2 \mathrm{~mA}$ per $12 \mathrm{~cm}$ of gel width overnight, the gels were soaked in saline for $2 \mathrm{~d}$ and given a change of saline after the first day. After washing with distilled water and drying the gels, protein was stained with Coomassie blue G-250 in $3.4 \%(\mathrm{w} / \mathrm{v})$ perchloric acid.

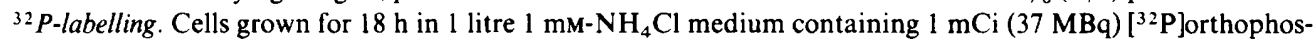
phoric acid (ICN Radiochemicals) were harvested before and after ammonia shock treatment. The final concentration of phosphate was $0.26 \mathrm{mM}$ after inoculation, and about $20 \%$ of the radioactivity was recovered in harvested cells. Cell-free extracts $(0.5 \mathrm{ml})$, prepared as above followed by ultracentrifugation at $80000 \mathrm{~g}$ for $1.5 \mathrm{~h}$, were mixed with purified anti-GDH antibody $\left(2 \mathrm{mg} \mathrm{ml}^{-1}\right)$. After $1 \mathrm{~h}$ incubation at room temperature, mixtures were centrifuged and pellets were washed twice with $50 \mathrm{~mm}$-Tris/HCl-containing saline $(\mathrm{pH} 7.8)$ and suspended in $50 \mu \mathrm{l} 50 \mathrm{~mm}-\mathrm{Tris} / \mathrm{HCl} \mathrm{pH} \mathrm{7.8}$. Purified GDH and the precipitates containing 750-1650 c.p.m. were subjected to SDS-PAGE (Laemmli, 1970). Gels were stained for protein, dried, and then used for autoradiography. Detection of radioactivity was done by exposing an X-ray film (Kodak X-Omat AR) for $9 \mathrm{~d}$ at $-75^{\circ} \mathrm{C}$. Cerenkov radiation from ${ }^{32} \mathrm{P}$ was counted as radioactivity by a liquid scintillation counter (Beckman LS-230).

Calculation of GDH molecular activity. Values were estimated using the assumptions that the molecular mass of the GDH is 300000 (Yamamoto et al., 1987) and that all material cross-reacting with the anti-GDH antiserum was the GDH protein. The molecular activity was defined as mol substrate reacted $\min ^{-1}$ (mol enzyme) ${ }^{-1}$. 
Table 1. Specific activities and immuno-reactive protein content of GDH in extracts from B. fragilis grown at different concentrations of $\mathrm{NH}_{4} \mathrm{Cl}$

Cells were harvested after $18 \mathrm{~h}$ growth in defined medium. Specific activities are expressed as units (mg protein $)^{-1}$, amount of immuno-reactive protein as $\mu \mathrm{g}(\mathrm{mg} \text { protein })^{-1}$, and molecular activities as $\mathrm{min}^{-1}$. Results are the mean values of two determinations for each extract, which differed from each other by no more than $10 \%$.

\begin{tabular}{|c|c|c|c|c|}
\hline \multirow[b]{2}{*}{$\begin{array}{l}\mathrm{NH}_{4} \mathrm{Cl} \text { concn } \\
(\mathrm{mM})\end{array}$} & \multirow[b]{2}{*}{$\mathrm{OD}_{650}$} & \multicolumn{3}{|c|}{ GDH } \\
\hline & & $\begin{array}{l}\text { Specific } \\
\text { activity }\end{array}$ & $\begin{array}{l}\text { Amount of immuno- } \\
\text { reactive protein }\end{array}$ & $\begin{array}{l}\text { Molecular } \\
\text { activity }\end{array}$ \\
\hline 1 & 0.385 & $5 \cdot 11$ & $82 \cdot 2$ & 18700 \\
\hline 5 & 0.714 & $3 \cdot 17$ & $56 \cdot 2$ & 16900 \\
\hline 10 & $1 \cdot 293$ & 1.55 & $42 \cdot 1$ & 11000 \\
\hline 50 & $2 \cdot 160$ & 0.458 & $44 \cdot 5$ & 3090 \\
\hline 100 & 2.095 & 0.482 & 37.8 & 3840 \\
\hline
\end{tabular}

\section{RESULTS}

Regulation of GDH synthesis

B. fragilis was grown in media containing $\mathrm{NH}_{4} \mathrm{Cl}$ at different concentrations, and the specific activity of GDH and the amount of protein immuno-precipitated with the antiserum against the enzyme were determined in crude extracts (Table 1). The specific activity was highest in $1 \mathrm{mm-}$ $\mathrm{NH}_{4} \mathrm{Cl}$-grown cells. Cells grown on $50 \mathrm{~mm}$ - or $100 \mathrm{~mm}-\mathrm{NH}_{4} \mathrm{Cl}$ showed a specific activity onetenth of that for $1 \mathrm{~mm}-\mathrm{NH}_{4} \mathrm{Cl}$-grown cells. The content of immuno-reactive protein was also the highest, $8 \%$ of the total protein, in $1 \mathrm{mM}-\mathrm{NH}_{4} \mathrm{Cl}$-grown cells, while it was about $4 \%$ for cells grown in $10 \mathrm{mM}^{-}, 50 \mathrm{mM}-$ and $100 \mathrm{~mm}-\mathrm{NH}_{4} \mathrm{Cl}$. The molecular activity of the GDH was $18700 \mathrm{~min}^{-1}$ in the $1 \mathrm{~mm}-\mathrm{NH}_{4} \mathrm{Cl}$-grown cells. This value was six times that for $50 \mathrm{~mm}$ - or $100 \mathrm{mM}-\mathrm{NH}_{4} \mathrm{Cl}$-grown cells. These findings suggest that in $B$. fragilis the synthesis of GDH is stimulated by less than $10 \mathrm{~mm}$-ammonia and that the enzyme has active and inactive forms depending on the ammonia concentration in the growth medium.

To confirm these observations, cells grown in a $50 \mathrm{mM}-\mathrm{NH}_{4} \mathrm{Cl}$ medium were transferred to a fresh medium containing $0.5 \mathrm{mM}-\mathrm{NH}_{4} \mathrm{Cl}$, and the enzyme activity and the immuno-reactive protein were determined in cell-free extracts (Fig. 1). After $3 \mathrm{~h}$ incubation, the specific activity increased by about $50 \%$, although the amount of immuno-reactive protein did not increase, indicating that the enzyme was activated during the incubation of cells in the ammonia-limited medium. After $9 \mathrm{~h}$ incubation, the specific activity and the amount of immuno-reactive protein increased about 4- and 1-5-fold, respectively. The molecular activity was thus raised from $2820 \mathrm{~min}^{-1}$ to $6660 \mathrm{~min}^{-1}$. After $24 \mathrm{~h}$ incubation with $50 \mu \mathrm{g}$ chloramphenicol $\mathrm{ml}^{-1}$, a $50 \%$ increase in the specific activity was observed, whereas a small drop $(10-20 \%)$ in the amount of immuno-reactive protein and a decrease in the $\mathrm{OD}_{650}$ of the culture by $20 \%$ were also observed; the molecular activity was $5220 \mathrm{~min}^{-1}$ in this culture. These results indicate that synthesis of GDH is induced under ammonia-limited conditions, and activation of the enzyme occurs posttranslationally also under ammonia-limited conditions.

\section{In vivo inactivation and reactivation}

When growth in a $1 \mathrm{mM}-\mathrm{NH}_{4} \mathrm{Cl}$ medium reached stationary phase, a culture was subjected to ammonia shock by the addition of $\mathrm{NH}_{4} \mathrm{Cl}$ to a final concentration of $50 \mathrm{~mm}$. The activity of GDH was assayed in crude extracts from shocked and unshocked cultures (Fig. 2). The NADPH-linked activity of GDH decreased by $80 \%$ within $15 \mathrm{~min}$ of ammonia shock. The molecular activity of the enzyme decreased from $19270 \mathrm{~min}^{-1}$ to $3700 \mathrm{~min}^{-1}$. The NADHdependent activity of the enzyme also decreased to the same extent (data not shown). The decrease in antigen content was accompanied by the growth of cells after ammonia shock. Thus, the total amount of the immuno-precipitated protein which was estimated in terms of GDH content $\times$ cell amount $\left(\mathrm{OD}_{650}\right)$ was almost constant for at least $2 \mathrm{~h}$ after ammonia shock. The 


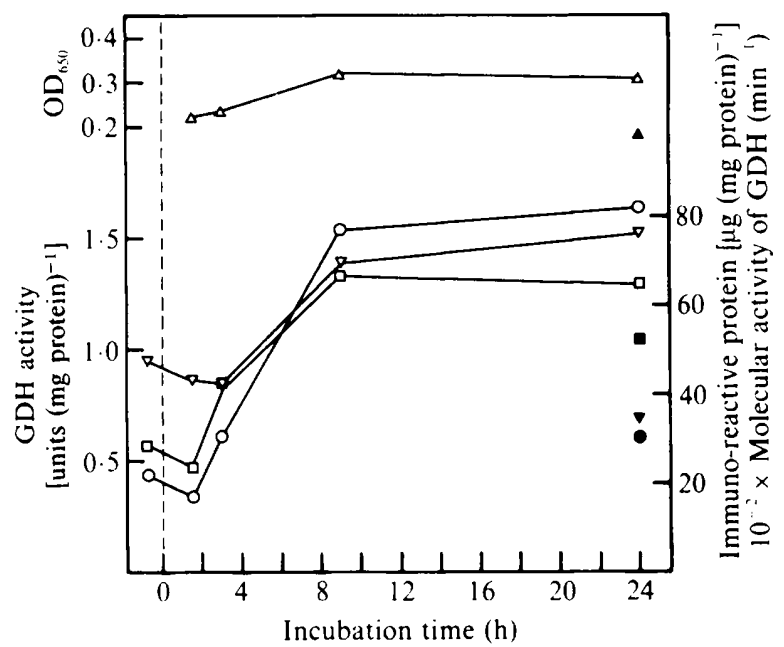

Fig. 1. Induction and activation of the dual coenzyme-specific GDH in $B$. fragilis under low ammonia conditions. Cells from an $18 \mathrm{~h}$ culture in $50 \mathrm{mM}-\mathrm{NH}_{4} \mathrm{Cl}$ were transferred to the defined medium containing $0.5 \mathrm{mM}-\mathrm{NH}_{4} \mathrm{Cl}$ (open symbols) and also to that containing $0.5 \mathrm{~mm}-\mathrm{NH}_{4} \mathrm{Cl}$ plus chloramphenicol $\left(50 \mu \mathrm{g} \mathrm{ml}^{-1}\right.$, filled symbols). Enzyme activity and immuno-reactive protein (protein precipitated with anti-GDH antiserum) were assayed in crude extracts prepared from the cells by sonication. $\mathrm{O}, \boldsymbol{O}$, Specific activity of $\mathrm{GDH} ; \nabla, \nabla$, immuno-reactive protein; $\square$, $\square$, molecular activity of $\mathrm{GDH} ; \triangle, \triangle, \mathrm{OD}_{650}$. Results are the mean values of two determinations for each sample, which differed from each other by no more than $10 \%$

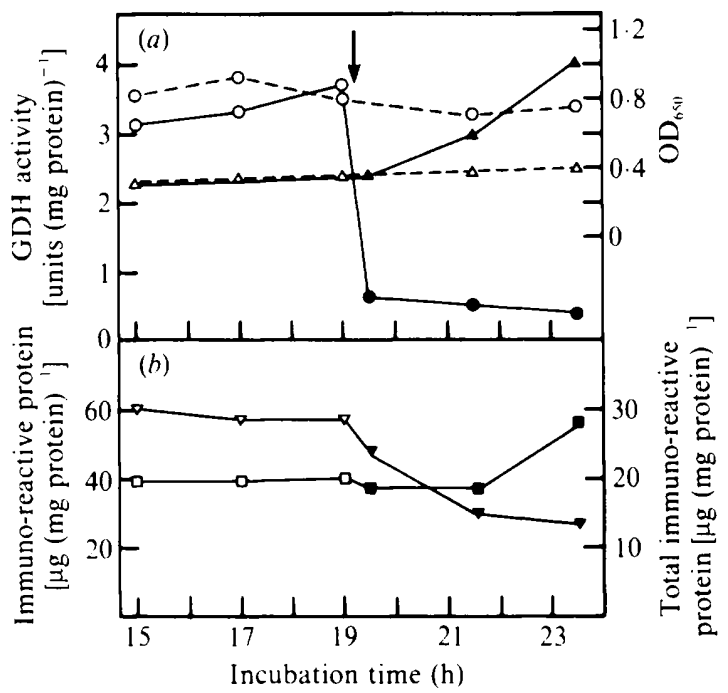

Fig. 2. Effect of ammonia shock on GDH activity in $B$. fragilis growing in medium containing $1 \mathrm{~mm}-$ $\mathrm{NH}_{4} \mathrm{Cl}$. $\mathrm{NH}_{4} \mathrm{Cl}$ (to a final concentration of $50 \mathrm{mM}$ ) was added to the culture in the stationary phase of growth at the time indicated with an arrow (solid lines). Another culture without the shock treatment (dashed lines) was grown in parallel. Samples were taken to prepare crude extracts from the cells. $\triangle, \Delta$, $\mathrm{OD}_{650} ; \mathrm{O}, \boldsymbol{O}$, specific activity of $\mathrm{GDH} ; \nabla, \nabla$, immuno-reactive protein; $\square, \boldsymbol{\square}$, total immunoreactive protein $\left(\mathrm{OD}_{650} \times\right.$ amount of immuno-reactive protein). The results obtained after ammonia shock are represented by filled symbols. Results are the mean values of two determinations for each sample, which differed from each other by no more than $10 \%$. 
Table 2. Effects of salts on GDH activity in $B$. fragilis

Each salt indicated was added to a $20 \mathrm{~h}$ culture initially containing $1 \mathrm{~mm}-\mathrm{NH}_{4} \mathrm{Cl}$, and the cells were harvested after incubation for $15 \mathrm{~min}$. The specific activity of GDH was measured in cell-free extracts. Results are the mean values of two determinations for each extract, which differed from each other by no more than $10 \%$.

\begin{tabular}{lccc}
\multicolumn{1}{c}{$\begin{array}{c}\text { Concn } \\
\text { (mM) }\end{array}$} & $\overbrace{\begin{array}{c}\text { Units } \\
\text { (mg protein })^{-1}\end{array}}^{\text {GDH specific activity }}$ \\
$\begin{array}{l}\text { No addition } \\
\mathrm{NH}_{4} \mathrm{Cl}\end{array}$ & 5 & 1.97 & 100 \\
& 15 & 1.00 & 51 \\
& 30 & 0.643 & 33 \\
& 50 & 0.661 & 34 \\
$\mathrm{NaCl}$ & 80 & 0.643 & 33 \\
$\mathrm{KCl}_{\mathrm{CH}} \mathrm{NH}_{2} . \mathrm{HCl}^{*}$ & 50 & 0.533 & 27 \\
$\mathrm{NH}_{2} \mathrm{OH} . \mathrm{HCl}^{*}$ & 50 & 1.86 & 94 \\
& 50 & 2.13 & 108 \\
& 50 & 2.04 & 104 \\
& & 1.86 & 94
\end{tabular}

double immunodiffusion test showed a single fused band without a spur between crude extracts from shocked and unshocked cells, and immunoelectrophoresis also showed a single precipitin band in each extract. The relative mobility of the enzyme in each crude extract was the same when examined by PAGE. These observations indicate that the decrease in enzyme activity following the addition of ammonium chloride was not due to degradation of the enzyme, and that the enzyme is probably converted to an inactive form.

Preparations of GDH, precipitated with a GDH-specific antibody from high-speed supernatants of ammonia-shocked and -unshocked cells grown in $\left[{ }^{32} \mathrm{P}\right]$ phosphate-containing medium, were analysed by SDS-PAGE. The amounts of phosphorus and GDH protein applied to the gel were about $1 \mathrm{nmol}$ and $10 \mu \mathrm{g}$, calculated from the radioactivity and density of stained protein respectively. However, no radioactivity was detected in GDH protein by autoradiography. The antibody-antigen complexes from shocked and unshocked cells were identical in SDS-PAGE, with no degradation product of GDH visible after ammonia shock.

The kind of compound that would trigger the inactivation of GDH was examined by adding salts or ammonia analogues to $18 \mathrm{~h}$ cultures originally containing $1 \mathrm{mM}-\mathrm{NH}_{4} \mathrm{Cl}$ (Table 2 ). $\mathrm{NH}_{4} \mathrm{Cl}$ at $5 \mathrm{~mm}$ decreased the activity by $50 \%$, and almost maximum inactivation occurred at $15 \mathrm{~mm}$. The other salts, $50 \mathrm{~mm}-\mathrm{KCl}$ and $50 \mathrm{~mm}-\mathrm{NaCl}$, showed no effect. This suggests that ammonia or the ammonium ion is the effector inducing inactivation, and not the chloride ion. No changes in enzyme activity were observed after the addition of the ammonia analogues monomethylamine and hydroxylamine (Table 2). When cells were suspended in medium lacking glucose or in Tris/ $\mathrm{HCl}$ buffer $(50 \mathrm{~mm}, \mathrm{pH} \mathrm{7.4})$, incubated anaerobically at $37^{\circ} \mathrm{C}$ for $1.5 \mathrm{~h}$, and then exposed to ammonia shock, decreases of $80 \%$ in the specific activity of the enzyme were observed (data not shown). The inactivation of GDH may therefore be energy-independent in B. fragilis.

To test whether the inactivation of GDH was reversible, cells exposed to ammonia shock were washed and transferred to two fresh media, one containing $0.5 \mathrm{mM}-\mathrm{NH}_{4} \mathrm{Cl}$ and the other containing $0.5 \mathrm{~mm}-\mathrm{NH}_{4} \mathrm{Cl}$ plus $50 \mu \mathrm{g}$ chloramphenicol ml $\mathrm{ml}^{-1}$. By removing the high concentration of ammonia, the enzyme activity recovered to about $90 \%$ of that observed before the ammonia shock (Fig. 3). No increase in the content of immuno-reactive protein was observed during $7 \mathrm{~h}$ incubation in the presence or absence of chloramphenicol after the transfer.

\section{DISCUSSION}

In order to investigate the regulatory mechanisms for the dual coenzyme-specific GDH of $B$. fragilis, immunochemical methods were used with a GDH-specific antiserum. The synthesis of 


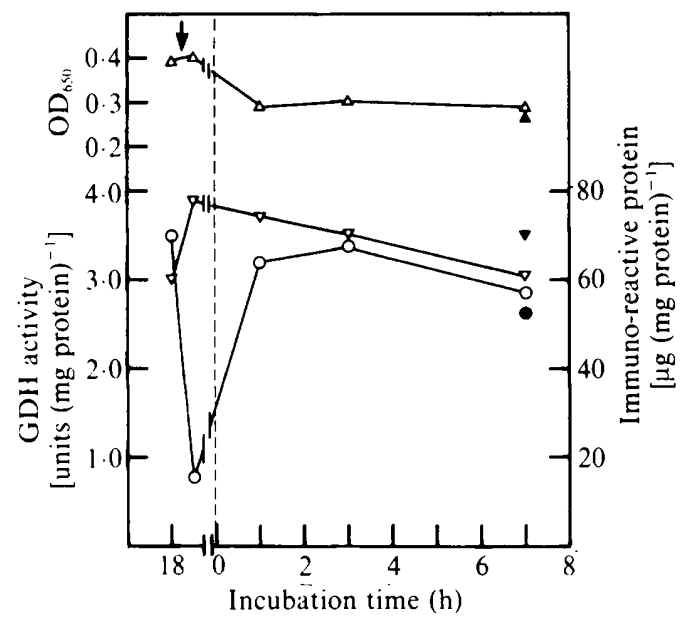

Fig. 3. Reversibility of the inactivation of the dual coenzyme-specific GDH. A stationary-phase culture grown with $1 \mathrm{mM}-\mathrm{NH}_{4} \mathrm{Cl}$ was shocked by the addition of $50 \mathrm{mM}-\mathrm{NH}_{4} \mathrm{Cl}$ at the time indicated by the arrow, and then washed with a sterile buffer. The washed cells were transferred to a defined medium containing $0.5 \mathrm{mM}-\mathrm{NH}_{4} \mathrm{Cl}$ (open symbols) or to another medium containing $0.5 \mathrm{~mm}-\mathrm{NH}_{4} \mathrm{Cl}$ and chloramphenicol $\left(50 \mu \mathrm{g} \mathrm{ml}^{-1}\right.$, filled symbols). Symbols are the same as in Fig. 1. Results are the mean values of two determinations for each sample, which differed from each other by no more than $10 \%$.

GDH was regulated in response to the concentration of extracellular ammonia. Immuno-

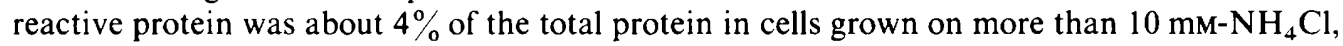
while it was twice that level at lower concentrations. Moreover, the synthesis of the enzyme protein was induced when the cells grown with $50 \mathrm{mM}-\mathrm{NH}_{4} \mathrm{Cl}$ were transferred to a low ammonia medium. It is likely that a large amount of the enzyme is synthesized to incorporate ammonia under ammonia-limited conditions. Such regulation of the synthesis of GDH appears to be unique to $B$. fragilis. The anaerobic rumen bacterium Selenomonas ruminantium also has a dual coenzyme-specific GDH, the activity of which decreased while growing on limited ammonia (Smith et al., 1980). In many bacteria the NADP+-specific GDH which functions in glutamate synthesis is induced by ammonia and repressed by glutamate or other amino acids (Smith et al., 1975).

GDH in cells was inactivated within $15 \mathrm{~min}$ by ammonia shock and GDH activity was recovered without synthesis of GDH protein by removing high concentrations of ammonia from the growth medium. This indicates the presence of another regulatory mechanism for GDH in $B$. fragilis, namely a reversible inactivation caused by changes in the extracellular ammonia concentration. Ammonia shock is known to cause the inactivation of glutamine synthetase in Escherichia coli due to the adenylylation/deadenylylation control mechanism (Stadtman \& Ginsburg, 1974). The energy-dependent inactivation of some enzymes has also been found in micro-organisms (Switzer, 1977). Other mechanisms for inactivation of microbial enzymes have also been found. Degradation inactivation of NADP+-dependent GDH occurs in Pseudomonas aeruginosa (Smits et al., 1984), Candida utilis (Hemmings, 1978a) and Saccharomyces cerevisiae (Mazon \& Hemmings, 1979; Bogonez et al., 1985). Protein phosphorylation is also known to be a regulatory mechanism for $\mathrm{NAD}^{+}$-dependent GDH in $C$. utilis (Hemmings, 1978b, 1981) and $S$. cerevisiae (Hemmings, 1980), and for isocitrate dehydrogenase in E. coli (Garnak \& Reeves, 1979 ) and Salmonella typhimurium (Wang \& Koshland, 1981). The inactivation of the $B$. fragilis GDH is unlikely to be due to its degradation, since a single protein with the same mobility was detected immunoelectrophoretically in each extract from shocked and unshocked cells and the amount of immuno-precipitated protein was not decreased by ammonia shock. Phosphorylation or adenylylation of the enzyme was also excluded as the cause of the inactivation or activation mechanism, because no phosphorylated forms of the enzyme were detected autoradiographically in either shocked or unshocked cells grown with ${ }^{32} \mathrm{P}$-phosphate. 
The values obtained for the molecular activity of the GDH fell in a range of about $3000 \mathrm{~min}^{-1}$ to $19000 \mathrm{~min}^{-1}$. The activity seemed to alter in relation to the concentration of extracellular ammonia. The $B$. fragilis GDH, composed of six identical subunits (Yamamoto et al., 1987), may have multimolecular forms, in which subunits are modified by an unidentified compound in response to a rise in the ammonia concentration, similar to the adenylylated forms of glutamine synthetase in E. coli (Stadtman \& Ginsburg, 1974).

Inactivation of the GDH was reversible in whole cells. However, we have never succeeded in inactivating and activating the GDH in crude extracts even under anaerobic conditions. An active form of the GDH was recently purified 37-fold from crude extracts (Yamamoto et al., 1987) and 18-fold from high-speed supernatants of disrupted cells, in which GDH comprised $16 \%$ of soluble protein (unpublished results). These extents of purification of GDH activity were higher than those expected on the basis of GDH protein contents. This may have resulted from the removal of an inhibitory compound from the enzyme fraction. However, GDH activity was not increased by dialysis of each extract from shocked and unshocked cells. Studies are continuing in order to identify the modification mechanism of the enzyme.

This work was supported partly by a Grant-in-Aid for Scientific Research (no. 60771904) from the Ministry of Education, Science and Culture of Japan, and by a grant from the Yakult Institute.

\section{REFERENCES}

Bogonez, E., Satrustegui, J. \& Machado, A. (1985). The role of glutamate in modulating the synthesis and degradation of NADP-glutamate dehydrogenase from Saccharomyces cerevisiae. FEMS Microbiology Letters 26, 53-58.

Davis, B. J. (1964). Disc electrophoresis. 11. Method and application to human serum proteins. Annals of the New York Academy of Sciences 121, 404-427.

Finegold, S. M. (1977). Anaerobic Bacteria in Human Disease. New York, San Francisco and London: Academic Press.

Finegold, S. M., Attebery, H. R. \& Sutter, V. L. (1974). Effect of diet on human fecal flora: comparison of Japanese and American diets. American Journal of Clinical Nutrition 27, 1456-1469.

Garnak, M. \& ReEves, H. C. (1979). Phosphorylation of isocitrate dehydrogenase of Escherichia coli. Science 203, 1111-1112.

Glass, T. L. \& Hylemon, P. B. (1980). Characterization of a pyridine nucleotide-nonspecific glutamate dehydrogenase from Bacteroides thetaiotaomicron. Journal of Bacteriology 141, 1320-1330.

Hemmings, B. A. (1978a). Evidence for the degradation of nicotinamide adenine dinucleotide phosphate-dependent glutamate dehydrogenase of Candida utilis during rapid enzyme inactivation. Journal of Bacteriology 133, 867877.

Hemmings, B. A. (1978b). Phosphorylation of NADdependent glutamate dehydrogenase from yeast. Journal of Biological Chemistry 253, 5255-5258.

Hemmings, B. A. (1980). Phosphorylation and proteolysis regulate the NAD-dependent glutamate dehydrogenase from Saccharomyces cerevisiae. FEBS Letters 122, 297-302.

Hemmings, B. A. (1981). Reactivation of the phospho form of the NAD-dependent glutamate dehydrogenase by a yeast protein phosphatase. European Journal of Biochemistry 116, 47-50.

JOHNSTONE, A. \& THORPE, R. (1982). Immunochemistry in Practice. Oxford: Blackwell.
LAEMMLI, U. K. (1970). Cleavage of structural proteins during the assembly of the head of bacteriophage T4. Nature, London 227, 680-685.

Mazon, M. J. \& Hemmings, B. A. (1979). Regulation of Saccharomyces cerevisiae nicotinamide adenine dinucleotide phosphate-dependent glutamate dehydrogenase by proteolysis during carbon starvation. Journal of Bacteriology 139, 686-689.

Moore, W. E. C. \& Holdeman, L. V. (1974). Human fecal flora: the normal flora of 20 JapaneseHawaiians. Applied Microbiology 27, 961-979.

Shah, H. N. \& Williams, R. A. D. (1982). Dehydrogenase patterns in the taxonomy of Bacteroides. Journal of General Microbiology 128, 2955-2965.

Smith, C. J., Hespell, R. B. \& BRyant, M. P. (1980). Ammonia assimilation and glutamate formation in the anaerobe Selenomonas ruminantium. Journal of Bacteriology 141, 593-602.

Smith, E. L., Austen, B. M., Blumenthal, K. M. \& NYC, J. F. (1975). Glutamate dehydrogenase. In The Enzymes, vol. 11, 3rd edn, pp. 294-367. Edited by P. D. Boyer. New York, San Francisco \& London: Academic Press.

Smits, P. A. M. M., Pieper, F. R. \& VAN Der DRift, C. (1984). Purification of NADP-dependent glutamate dehydrogenase from Pseudomonas aeruginosa and immunochemical characterization of its in vivo inactivation. Biochimica et biophysica acta 801, 3239.

Stadtman, E. R. \& Ginsburg, A. (1974). The glutamine synthetase of Escherichia coli: structure and control. In The Enzymes, vol. 10, 3rd edn, pp. 755-807. Edited by P. D. Boyer. New York \& London: Academic Press.

SwITZER, R. L. (1977). The inactivation of microbial enzymes in vivo. Annual Review of Microbiology 31, $135-157$

VAREL, V. H. \& Bryant, M. P. (1974). Nutritional features of Bacteroides fragilis subsp. fragilis. Applied Microbiology 28, 251-257. 
Wang, J. Y. J. \& Koshland, D. E. (1981). The identification of distinct protein kinases and phosphatases in the prokaryote Salmonella typhimurium. Journal of Biological Chemistry 256, 4640-4648.

Yамamoto, I., ABE, A., SaIto, H. \& Ishimoto, M. (1984). The pathway of ammonia assimilation in
Bacteroides fragilis. Journal of General and Applied Microbiology 30, 499-508.

Yамамото, I., AвE, А. \& Ishimoto, M. (1987). Properties of glutamate dehydrogenase purified from Bacteroides fragilis. Journal of Biochemistry (Tokyo) 101, 1391-1397. 